\title{
Faktor-Faktor yang Mempengaruhi Konservatisme Akuntansi
}

\author{
Nur Afriani ${ }^{1}$, Zulpahmi $^{2}$, Sumardi ${ }^{3}$ \\ 1,2.3Program Studi Akuntansi, Fakultas Ekonomi dan Bisnis \\ Universitas Muhammadiyah Prof. DR. Hamka, Jakarta \\ 1nurafriani04@gmail.com
}

\begin{abstract}
Abstrak Tujuan dari penelitian ini adalah untuk mengetahui pengaruh financial distress, leverage, likuiditas, risiko litigasi, kepemilikan institusional, dan kepemilikan asing, konservatisme akuntansi pada perusahaan sektor BUMN yang terdaftar pada bursa efek indonesia periode 2014-2019. Populasi dalam penelitian ini adalah perusahaan BUMN yang terdaftar di Bursa Efek Indonesia (BEI), adapun teknik pengambilan sampel yang digunakan adalah purposive sampling dengan sampel yang terpilih sebanyak 8 (delapan) perusahaan. Teknik pengumpulan data dilakukan dengan telaah dokumen, yaitu pengumpulan data yang dilakukan dengan menelaah laporan keuangan perusahaan yang terdaftar di Bursa Efek Indonesia. Metode analisis yang digunakan adalah analisis regresi linear berganda. Hasil pengujian menunjukkan bahwa financial distress berpengaruh terhadap konservatisme akuntansi. Leverage berpengauh terhadap konservatisme akuntansi. Likuiditas tidak berpengaruh terhadap konservatisme akuntansi. Risiko litigasi tidak berpengaruh terhadap konservatisme akuntansi. Kepemilikan institusional tidak berpengauh terhadap konservatisme akuntansi. Kepemilikan asing berpengaruh terhadap konservatisme akuntansi. Variabel financial distress, leverage, likuiditas, risiko litigasi, kepemilikan institusional, kepemilikan asing secara simultan berpengaruh terhadap konservatisme akuntansi.
\end{abstract}

Kata Kunci : financial distress, leverage, likuiditas, risiko litigasi, kepemilikan institusional, kepemilikan asing dan konservatisme akuntansi

\section{Pendahuluan}

Prinsip akuntansi yang berterima umum (Generally Accepted Accounting Principles) memberikan kebebasan terhadap manajemen dalam menentukan metode akuntansi dan pelaporan keuangan perusahaan. Dengan adanya kebebasan ini, manajer dapat melakukan pelaporan keuangan yang optimis maupun pesimis. Pelaporan keuangan yang optimis serta cenderung melebih-lebihkan terkadang menyesatkan dan merugikan pengguna laporan keuangan. Selain itu kecenderungan untuk melebih-lebihkan dalam laporan keuangan dapat dikurangi dengan menerapkan sikap pesimisme untuk mengimbangi optimisme yang berlebihan. Konservatisme menjelaskan bahwa laporan keuangan yang konservatif dapat 
mencegah adanya information asymmetry dengan cara membatasi manajemen dalam memanipulasi laporan keuangan. Laba yang disajikan terlalu tinggi (overstatement) lebih berbahaya daripada penyajian laba yang rendah (understatement) karena risiko tuntutan hukum yang didapat akan lebih besar bila menyajikan laporan keuangan dengan laba yang jauh lebih tinggi dari sesungguhnya.

PT Garuda Indonesia Tbk pada tahun 2018 telah mengakui dan membukukan laba bersih sebesar US\$809,85 ribu atau setara Rp 11,33 miliar (Kurs 14.000) yang seharusnya masih dalam bentuk piutang. Hal ini lah yang pada akhirnya membuat beban yang ditanggung oleh PT Garuda Indonesia untuk membayar Pajak Penghasilan (PPh) dan Pajak Pertambahan Nilai (PPN) menjadi besar, padahal beban tersebut seharusnya belum menjadi kewajiban karena pembayaran dari kerjasama dengan PT Mahata belum diperoleh oleh PT. Garuda Indonesia. Kasus yang terjadi pada Garuda menunjukkan bahwa adanya kegagalan atas penerapan prinsip konservatisme akuntansi. Pihak manajemen (agen) perusahaan tidak berhati-hati dalam mengakui pendapatan yang seharusnya tidak diakui sehingga menyebabkan laporan keuangan overstatement terhadap laba bersih. Dalam hal ini, perusahaan memiliki optimisme dalam mengakui laba bersih sehingga menyebabkan angka laba meningkat lebih besar dari yang seharusnya.

Prinsip konservatisme sendiri masih di perdebatkan di mana dengan semakin mengarahnya perekonomian ke pasar bebas akan mendorong perusahaan semakin hati-hati dalam menyajikan segala aspek keuangan maupun aspek lainya. Ada beberapa faktor dalam menentukan keputusan manajer dalam mengunakan metode konservatif atau tidak. Faktor pertama yaitu financial distress. Tingkat kesulitan keuangan merupakan keadaan yang harus diperhatikan oleh manajemen, karena kondisi ini akan menunjukkan kekampuan perusahaan dalam memenuhi kebutuhan keuangannya. Kondisi keuangan yang bermasalah dapat medorong pergantian manajer. Dengan demikian, jika semakin tinggi tingkat kesulitan keuangan perusahaan maka semakin tinggi pula penerapan konservatisme akuntansi. Hal ini sesuai dengan penelitian yang dilakukan oleh Agung, Nurcholisa dan Nurhayati (2019), Putri (2018), dan Risdiyani (2015) sedangkan hasil penelitian tersebut tidak sesuai dengan penelitian yang dilakukan oleh Abdurrahman dan Ernawati (2018), Dewi dan Suryanawa (2014), dan Suprihatin (2019).

Faktor kedua yang diteliti adalah leverage. Penelitian sebelumnya yang dilakukan oleh Risdiyani dan Kumuriyanto (2015), Mulyani dan Juvenrio (2017), Hertina dan Zulaikha (2017), Arsanto (2017), Lestari (2020), Abdurrahman dan Ernawati (2018), Yuliarti dan Yanto (2017) dan Dewi dan Suryanawa (2014) yang menyatakan bahwa leverage berpengaruh positif dan signifikan terhadap konservatisme akuntansi, hasil tersebut berbeda dengan penelitian yang dilakukan oleh Ramdhani dan Nur (2015), Dewim, Herawati dan Sinarwati (2014) dan Noviantari dan Ratnadi (2015) menyatakan bahwa leverage tidak berpengaruh terhadap konservatisme akuntansi.

Faktor ketiga yaitu likuiditas yang telah diteliti oleh Nasir, Ilham, dan Yusniati menyatakan bahwa likuiditas berpengaruh signifikan terhadap konservatisme akuntansi. Hasil berbeda ditunjukkan oleh Pratanda dan Kumuriyanto (2015) yang menyatakan bahwa likuiditas tidak berpengaruh terhadap konservatisme akuntansi.

Faktor selanjutnya yaitu risiko litigasi dalam penelitian yang dilakukan oleh Rizkyka, Nurhayati, dan Fadilah (2019) dan Rahayu, Kusmuriyanto, Kiswanto dan Gunawan (2018) menyatakan bahwa risiko litigasi berpengaruh terhadap koservatisme akuntansi, hasil tersebut

\section{J u r a 1 B u a A A n t ansi}


berbeda dengan penellitian yang dilakukan oleh Pratama, Norita, Nurbaiti (2016) dan Pratama, Norita, Nurbaiti (2016) menyatakan bahwa risiko litigasi tidak berpengaruh terhadap konservatisme akuntansi.

Kepemilikan institusional yang diteliti oleh El-Haq, Zulpahmi, dan Sumardi (2019), dan Ramdhani, Nurcholisa, dan Nurhayati (2019) menyatakan bahwa adanya pengaruh signifikan dan positif terhadap konservatisme akuntansi. Sedangkan hasil tersebut tidak sejalan dengan Risdiyani dan Kusmuriyanto (2015), Syifa, Kristanti, dan Dillak (2017), Pratanda dan Kusmurianto (2014) yang menyatakan bahwa kepemilikan institusional tidak berpengaruh terhadap konservatisme akuntansi.

Kepemilikan asing merupakan proporsi saham biasa yang dimiliki oleh perusahaan baik perorangan, badan hukum, pemerintah serta bagian-bagiannya yang berstatus luar negeri atau bukan berasal dari Indonesia. Alkurdi., et al (2017) menyatakan bahwa kepemilikan asing berpengaruh positif terhadap konservatisme akuntansi, sedangkan Kuspratiwi dan Widagdo (2014) menyatakan bahwa kepemilikan asing berpengaruh secara signifikan terhadap konservatisme akuntansi. Hal ini berbeda dengan penelitian yang dilakukan oleh Asiriuwa., et al (2019) yang menunjukkan hasil bahwa kepemilikan asing berpengaruh negatif tidak signifikan terhadap konservatisme akuntansi. Berdasarkan dari penelitian terdahulu, penelitian ini bertujuan untuk mengetahui faktor-faktor yang mempengaruhi konservatisme akuntansi pada perusahaan BUMN yang terdaftar di Bursa Efek Indonesia periode 2014-2019.

\section{Tinjauan Pustaka}

\subsection{Konservatisme Akuntansi}

Konservatisme akuntansi adalah sikap atau aliran (mazhab) dalam menghadapi ketidakpastian untuk mengambil tindakan atau keputusan atas dasar munculan (outcome) yang buruk dari ketidakpastian tersebut. Sikap konservatisme juga mengandung makna sikap berhati-hati dalam mengambil resiko dengan cara bersedia mengorbankan sesuatu untuk mengurangi atau menghilangkan risiko (Suwardjono, 2014:245). Menurut glosarium FASB (Financial Accounting Standard Board) No. 2 Tahun 1987 dalam (Savitri, 2016 : 23), menyatakan bahwa konservatisme adalah reaksi yang hati-hati (prudent reaction) dalam menghadapi ketidakpastian yang melekat pada perusahaan untuk mencoba memastikan bahwa ketidakpastian dan risiko dalam lingkungan bisnis yang sudah cukup dipertimbangkan. Dalam penelitian ini pengukuran konservatisme menggunakan rumus akrual non operasi. Akrual non operasi memperlihatkan pencatatan kejadian buruk yang terjadi dalam perusahaan, contohnya pencadangan piutang tak tertagih, keuntungan dan kerugian dari penjualan aset, biaya restrukturisasi dan penghapusan aset. Akrual non operasi dapat dihitung dari seluruh aset yang dimiliki perusahaan sebelum adanya depresiasi namun tidak termasuk kas dari aktivitas operasi akrual yang timbul dari kegiatan operasional utama perusahaan (Givolyn dan Hayn, 2000). Rumus konservatisme akuntansi sebagai berikut:

Keterangan:

$$
\text { CONACC }=\frac{(\mathrm{NIO}+\mathrm{DEP}-\mathrm{CFO}) \mathrm{X}(-1)}{\mathrm{TA}}
$$

CONACC: Earning conservatism based on accrued items

NIO : Operating profit of current year

DEP : Depreciation of fixed assets of current year

\section{J u r a 1 B u a n A k untansi}


CFO : Net amount of cash flow from operating activities of current year TA : Book value of closing

\subsection{Financial Distress}

Menurut (Hery, 2016:33), kesulitan keuangan adalah Kesulitan keuangan adalah suatu keadaan di mana sebuah perusahaan mengalami kesulitan untuk memenuhi kewajibannya, keadaan di mana pendapatan perusahaan tidak dapat menutupi total biaya dan mengalami kerugian. Bagi kreditor, keadaan ini merupakan gejala awal kegagalan debitor". Sedangkan Menurut (Rusdianto, 2013:251), kesulitan keuangan adalah Ketidakmampuan perusahaan untuk membayar kewajiban keuangannya pada saat jatuh tempo yang menyebabkan kebangkrutan atau kesulitan likuiditas yang mungkin sebagai awal kebangkrutan.

Pengukuran financial distress dalam penelitian menggunakan metode Analisis Z- Score Altman, dimana Perusahaan yang mempunyai skor $Z>2.90$ dikatakan bahwa perusahaan tersebut dalam kondisi sehat (tidak bangkrut). Sedangkan perusahaan yang mempunyai skor $1,23 \leq Z<2.90$ diklasifikasikan sebagai perusahaan yang rawan bangkrut (grey area). Selanjutnya skor antara $Z<1.23$ diklasifikasikan sebagai perusahaan yang berpotensial bangkrut. Rumus yang digunakan sebagai berikut:

$$
\mathrm{Z}=6.56 \mathrm{~T}_{1}+3.26 \mathrm{~T}_{2}+6.72 \mathrm{~T}_{3}+1.05 \mathrm{~T}_{4}
$$

Keterangan:

$\mathrm{T}_{1}$ : working capital/total aset

$\mathrm{T}_{2}$ : retained earnings/total aset

$\mathrm{T}_{3}$ : earnings before interest and taxes/total aset

$\mathrm{T}_{4}$ : market value of equity/book value of total debt

\subsection{Leverage}

Menurut Fahmi (2013:185) leverage merupakan gambaran kemampuan suatu perusahaan dalam memenuhi dan menjaga kemampuannya untuk selalu mampu memenuhi kewajibannya dalam membayar utang secara tepat waktu. Leverage digunakan perusahaan untuk mengukur kondisi kemampuan perusahaan tersebut dalam membayar kewajiban jangka panjangnya, dinilai dari utang yang dibanding kan dengan aset perusahaan tersebut ataupun dengan modal sendiri (Susanto dan Ramdhani, 2016). Rumus leverage sebagai berikut:

\subsection{Likuiditas}

$$
\text { Debt to Asset }=\frac{\text { Total debt }}{\text { Total aset }}
$$

Likuiditas perusahaan menunjukan kemampuan untuk membayar kewajiban finansial jangka pendek tepat pada waktunya likuiditas perusahaan ditunjukan oleh besar kecilnya aktiva lancar yaitu aktiva yang mudah untuk diubah menjadi kas, surat berharga, piutang, dan persediaan (Agus Sartono, 2014:100). Rasio likuditas diukur dengan current ratio untuk mengetahui seberapa banyak aktiva lancar yang tersedia untuk menutupi kewajiban jangka pendek yang segera jatuh tempo. Rumus likuiditas sebagai berikut:

\section{3 |Jurnal Buana A kuntansi}




\subsection{Risiko Litigasi}

$$
\text { Current ratio }=\frac{\text { Current assets }}{\text { Current liabilities }}
$$

Menurut Septianto (2016), risiko litigasi adalah risiko yang melekat pada perusahaan yang memungkinkan terjadinya ancaman litigasi oleh pihak-pihak yang berkepentingan dengan perusahaan yang merasa dirugikan. pihak-pihak yang berkepentingan terhadap perusahaan meliputi kreditor, investor, dan regulator. Adapun indikator pengukuran risiko litigasi pada penelitian ini diukur menggunakan debt equity ratio (DER). Semakin besar DER maka semakin besar risiko litigasi yang akan dihadapi oleh perusahaan karena hutang jauh lebih besar dari ekuitas perusahaan yg digunakan untuk menutupi hutang kepada kreditor lainnya (Fitri, 2015). Rumus risiko litigasi sebagai berikut:

$$
\text { DER }=\frac{\text { Total Hutang }}{\text { Total Ektuitas }}
$$

\subsection{Kepemilikan Institusional}

Jumlah saham yang dimiliki pihak institusional dari seluruh jumlah saham yang beredar di BEI. Pihak institusional diantaranya perusahaan asuransi, bank, perusahaan-perusahaan investasi dan kepemilikan oleh institusi-institusi lain (Brilianti, 2013). Kepemilikan institusional diukur dengan membandingkan antara jumlah saham yang dimiliki oleh institusi dengan seluruh modal saham yang beredar. Rumus kepemilikan institusional sebagai berikut:

\subsection{Kepemilikan Asing}

$$
\text { Kepemilikan institusional }=\frac{\text { Jumlah lembar saham institusional }}{\text { Jumlah saham yang beredar }}
$$

Menurut Undang-Undang Republik Indonesia No. 25 Tahun 2007 Pasal 1 angka 6 tentang Penanaman Modal, kepemilikan asing adalah perseorangan warga Negara asing, badan usaha asing, dan/atau pemerintah asing yang melakukan penanaman modal di wilayah Negara Republik Indonesia. Kepemilikan asing dapat diukur sesuai dengan proporsi saham biasa yang dimiliki oleh asing. Rumus untuk menghitung persentase kepemilikan asing adalah sebagai berikut: (Anjani, 2018)

$$
\text { Kepemilikan asing }=\frac{\text { Jumlah saham yang dimiliki investor asing }}{\text { Jumlah saham yang beredar }}
$$




\section{Buana Akuntansi}

\subsection{Kerangka Pemikiran dan Hipotesis}

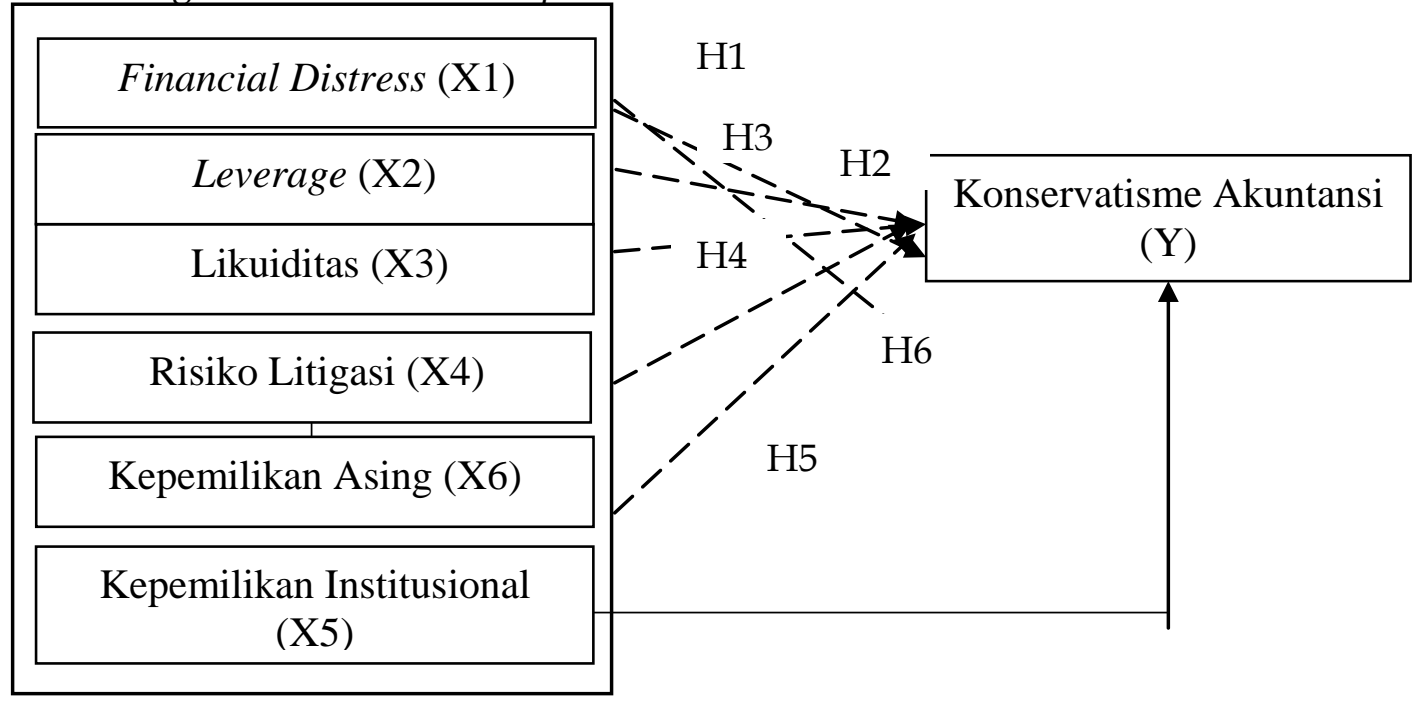

Keterangan:

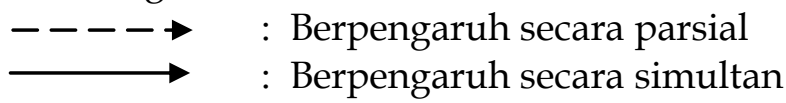

\section{Gambar 1. Kerangka Pemikiran}

Berdasarkan kerangka pemikiran teoritis yang telah diuraikan di atas, maka dirumuskan sebagai berikut:

$\mathrm{H}_{1}$ : Financial distress berpengaruh terhadap konservatisme akuntansi.

$\mathrm{H}_{2}$ : Leverage berpengaruh terhadap konservatisme akuntansi.

$\mathrm{H}_{3}$ : Likuiditas berpengaruh terhadap konservatisme akuntansi.

$\mathrm{H}_{4}$ : Risiko litigasi berpengaruh terhadap konservatisme akuntansi.

$\mathrm{H}_{5}$ : Kepemilikan institusional berpengaruh terhadap konservatisme akuntansi.

$\mathrm{H}_{6}$ : Kepemilikan asing berpengaruh terhadap konservatisme akuntansi.

\section{Metodologi Penelitian}

Penelitian ini menggunakan metode eksplanasi. Metode eksplanasi merupakan metode penelitian yang bertujuan untuk menjelaskan kedudukan variabel-variabel yang diteliti serta hubungan antara satu variabel (Sugiyono, 2014:11). Penelitian ini bertujuan untuk menguji pengaruh antara variabel indepeden yaitu financial distress, leverage, likuiditas, risiko litigasi, kepemilikan institusional dan kepemilikan asing terhadap variabel dependen yaitu konservatisme akuntansi. Penelitian ini dilakukan pada perusahaan BUMN yang terdaftar di Bursa Efek Indonesia (BEI). Data diambil melalui situs www.idx.co.id berupa laporan keuangan perusahaan BUMN. Populasi dalam penelitian ini sebanyak 20 perusahaan. Pengambilan sampel menggunakan teknik purposive sampling dengan 


\section{Buana Akuntansi}

menetapkan kriteria tertentu sehingga ditetapkan sebanyak 8 (delapan) perusahaan BUMN periode 2014-2019.

\section{Analisis dan Pembahasan}

4.1. Statistik Deskriptif

Tabel 1. Hasil Analisis Deskriptif

Descriptive Statistics

\begin{tabular}{|l|r|r|r|r|r|}
\hline \multicolumn{2}{|c}{ N } & \multicolumn{1}{c|}{ Minimum } & Maximum & Mean & Std. Deviation \\
FD & 48 & 1.25 & 7.91 & 4.1674 & 1.71826 \\
LEV & 48 & .27 & .84 & .5001 & .14639 \\
LIK & 48 & .37 & 2.59 & 1.4702 & .55132 \\
RL & 48 & .42 & 9.24 & 1.8195 & 1.67050 \\
KI & 48 & .03 & .86 & .2271 & .23344 \\
KA & 48 & .00 & .39 & .1736 & .13422 \\
CONACC & 48 & .02 & .70 & .2340 & .18897 \\
Valid N (listwise) & 48 & & & & \\
\hline
\end{tabular}

Sumber: Output SPSS 26

Berdasarkan tabel 1 dapat diketahui bahwa dalam penelitian ini terdapat 48 data observasi, hal tersebut dapat dilihat dari nilai $\mathrm{N}$ yang memiliki nilai 48. Financial distress (FD) memiliki nilai minimum sebesar 1.25; nilai maximum sebesar 7.91; nilai mean sebesar 4.1674 dan standar deviasi sebesar 1.71826. Leverage (LEV) memiliki nilai minimum sebesar 0.27; nilai maximum sebesar 0.84; nilai mean sebesar 0.5001 dan standar deviasi sebesar 0.14638. Likuiditas (LIK) memiliki nilai minimum sebesar 0.37; nilai maximum sebesar 2.59; nilai mean likuiditas sebesar 1.4702 dan standar deviasi sebesar 0.55132 . Risiko litigasi (RL) memiliki nilai minimum sebesar 0.42; nilai maximum sebesar 9.24; nilai mean risiko litigasi sebesar 1.8195 dan standar deviasi sebesar 1.67050. Kepemilikan institusioanl (KI) memiliki nilai minimum sebesar 0.03; nilai maximum sebesar 0.86; nilai mean kepemilikan institusional sebesar 0.2271 dan standar deviasi sebesar 0.23344. Kepemilikan asing (KA) memiliki nilai minimum sebesar 0.00; nilai maximum sebesar 0.39; nilai mean kepemilikan asing sebesar 0.1736 dan standar deviasi sebesar 0.13422 . Konservatisme akuntansi (CONACC) memiliki nilai minimum sebesar 0.02; nilai maximum sebesar 0.70; nilai mean kosnervatisme akuntansi sebesar 0.2340 dan standar deviasi sebesar 0.18897 .

\subsection{Asumsi Klasik}

Uji normalitas bertujuan untuk menguji apakah dalam model regresi terdapat variabel penganggu atau residual memiliki distribusi normal. Uji normalitas pada penilitian ini menggunakan uji One-Sample Kolmogrov-Smirnov Test (K-S) dengan melihat Asymp. Sig. (2tailed) $>0.05$. 
Tabel 2. Hasil Uji Kolmogorov-Smirnov Test One-Sample Kolmogorov-Smirnov Test

\begin{tabular}{|ll|r|}
\hline $\mathrm{N}$ & & \multicolumn{2}{c|}{$\begin{array}{c}\text { Unstandardized } \\
\text { Residual }\end{array}$} \\
Normal Parameters & Mean & 47 \\
& Std. & .0100918 \\
& Deviation & .10491724 \\
Most Extreme & Absolute & .107 \\
Differences & Positive & .107 \\
& Negative & -.071 \\
Test Statistic & & .107 \\
Asymp. Sig. (2-tailed) & & .200 \\
\hline
\end{tabular}

Sumber: Output SPSS 26

Dapat dilihat dari tabel diatas, hasil dari uji normalitas Kolmogrov-Smirnov Test (K-S) menunjukkan bahwa nilai Asymp. Sig. (2-tailed) sebesar $0.200>0.05$. Hal ini menunjukkan bahwa model regresi memenuhi asumsi normalitas karena tingkat signifikansinya sebesar 0.05.

Uji multikolinearitas bertujuan untuk menguji apakah model regresi ditemukan adanya korelasi antara variabel bebas (independen) atau tidak. Model regresi yang baik seharusnya tidak terjadi korelasi antar variabel independen. Untuk menguji ada tidaknya multikolinearitas dapat menggunakan nilai tolerance value atau Variance Inflation Factor (VIF).

\begin{tabular}{|c|c|c|c|}
\hline & & \multicolumn{2}{|c|}{ Collinearity Statistics } \\
\hline Model & & Tolerance & VIF \\
\hline 1 & (Constant) & & \\
\hline & FD & .268 & 3.730 \\
\hline & LEV & .296 & 3.373 \\
\hline & LIK & .316 & 3.163 \\
\hline & RL & .573 & 1.745 \\
\hline & $\mathrm{KI}$ & .724 & 1.382 \\
\hline & KA & .463 & 2.159 \\
\hline
\end{tabular}

Sumber: Output SPSS 26

Dari tabel diatas menunjukkan bahwa nilai tolerance dari variabel dependen tidak terdapat nilai yang kurang dari 0.10 (tolerance $>0.10$ ) yang berarti tidak ada korelasi antar variabel independen. Hasil dari perhitungan Variance Inflation Factor (VIF) juga menunjukkan nilai antar variabel independen kurang dari 10 (VIF < 10). Maka dapat disimpulkan bahwa dalam penelitian ini tidak mengalami gejala multikolinearitas.

Model regresi yang baik adalah model regresi yang tidak mengalami autokorelasi. Uji autokorelasi bertujuan untuk mengetahui apakah dalam model regresi liniear ada korelasi antara kesalahan penggangu pada periode $t$ dengan kesalahan pengganggu pada periode t-1 (sebelumnya). Uji autokorelasi dalam penelitian ini dilakukan dengan

\section{7 | J r n a 1 B u a a A k ntansi}




\section{Buana Akuntansi}

NAMA PENELITI

Vol.6 No.1

ISSN 2528-1119

E-ISSN 2580-5452

cara membandingkan antara nilai durbin Watson (dW) dengan nilai dU. Jika nilai durbin Watson terletak pada $\mathrm{dU}<\mathrm{dW}<4-\mathrm{dU}$ maka penelitian terbebas dari gejala autokorelasi.

Tabel 4. Hasil Uji Autokorelasi Model Summary

\begin{tabular}{|c|c|c|c|c|c|}
\hline Model & $\mathrm{R}$ & $\mathrm{R}$ Square & $\begin{array}{c}\text { Adjusted R } \\
\text { Square }\end{array}$ & $\begin{array}{c}\text { Std. Error } \\
\text { of the } \\
\text { Estimate }\end{array}$ & $\begin{array}{c}\text { Durbin- } \\
\text { Watson }\end{array}$ \\
\hline 1 & $.716^{\mathrm{a}}$ & .513 & .442 & .11165 & 1.849 \\
\hline
\end{tabular}

Sumber: Output SPSS 26

Berdasarkan tabel diatas nilai durbin Watson $=1.849$; nilai $\mathrm{dU}=1.8265$ yang dilihat dari tabel durbin Watson dengan nilai signifikasi sebesar 0.05 , jumlah pengamatan $(\mathrm{n})=$ 48 , dan jumlah variabel bebas $(k)=6$ serta nilai $4-d U=2.1735$. Maka dapat disimpulkan bahwa data dalam penelitian ini tidak mengalami gejala autokorelasi. Hal ini dapat dibuktikan dari nilai durbin Watson yang tertelak pada rentang $\mathrm{dU}<\mathrm{dW}<4$-dU $=$ $1.8265<1.849<2.1735$.

Uji heterokedastisitas bertujuan untuk menguji apakah model regresi memiliki kesamaan varians dari residual pengamatan satu ke pengamatan yang lainnya (Ghozali, 2016:130). Pada penelitinan ini, uji heteroskedasitas dilakukan dengan melihat grafik plot antara nilai prediksi variabel terikat (dependen) yaitu ZPRED dengan residualnya SRESID. Jika tidak ada pola tertentu dan tidak menyebar diatas dan dibawah angka nol pada sumbu $y$, maka tidak terjadi heteroskedastisitas.

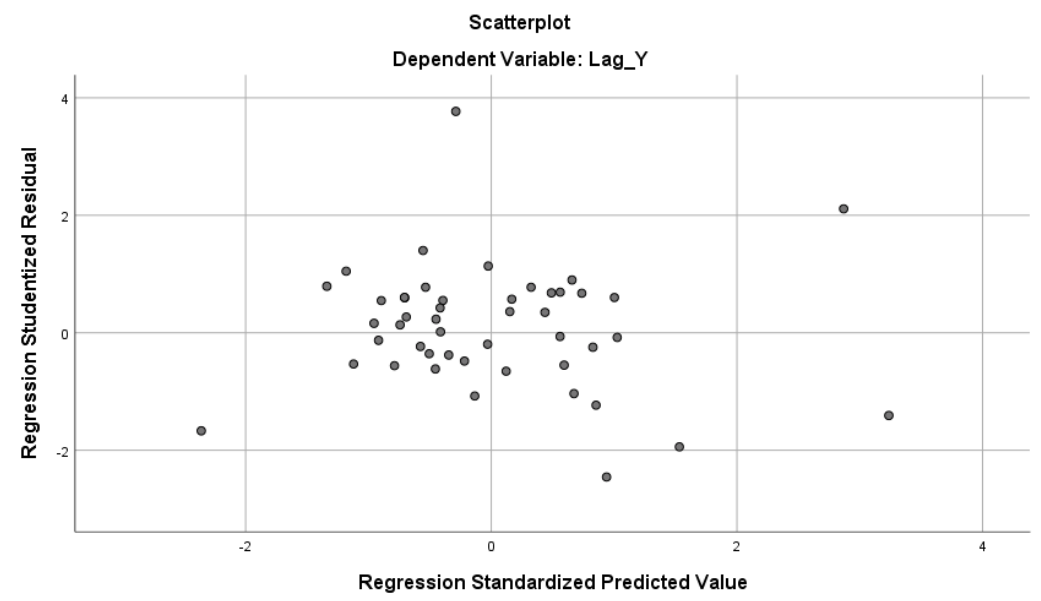

Gambar 2. Hasil Uji Heterokedastisias 


\section{Buana Akuntansi}

\subsection{Analisis Regresi Linear Berganda}

Tabel 5. Hasil Uji Koefisien Regresi Coefficients ${ }^{a}$

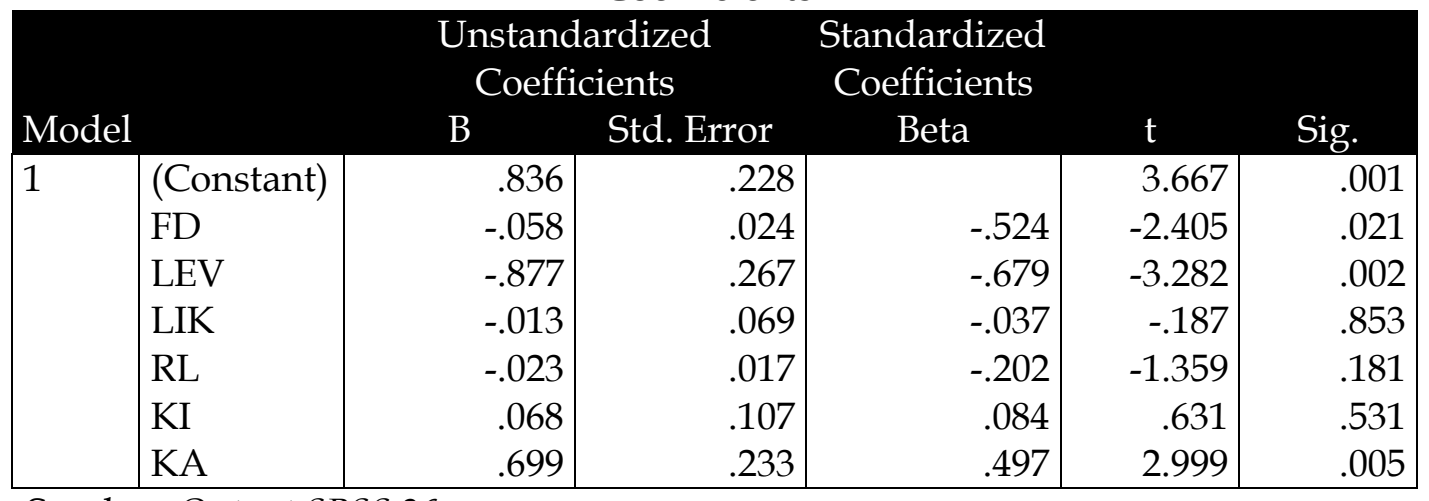

Sumber: Output SPSS 26

Dari tabel diatas maka dapat diperoleh hasil persamaan regresi sebagai berikut:

$\mathrm{Y}=0.836-0.058 \mathrm{X} 1-0.877 \mathrm{X} 2-0.13 \mathrm{X} 3-0.23 \mathrm{X} 4+0.68 \mathrm{X} 5+0.699 \mathrm{X} 6$

Dari persamaan regresi linear berganda diatas dapat diinterpretasikan sebagai berikut:

1. Konstanta sebesar 0.836 , artinya jika financial distress $\left(X_{1}\right)$, leverage $\left(X_{2}\right)$, likuiditas $\left(X_{3}\right)$, risiko litigasi $\left(X_{4}\right)$, kepemilikan institusional $\left(X_{5}\right)$, kepemilikan asing $\left(X_{6}\right)$ bernilai 0 (nol), maka konservatisme akuntansi $(\mathrm{Y})$ mengalami kenaikan sebesar 0.836.

2. Koefisien regresi financial distress $\left(\mathrm{X}_{1}\right)$ sebesar -0.058 artinya jika financial distress mengalami peningkatan sebesar 1\%, maka akan diikuti penurunan konservatisme akuntansi (Y) sebesar -0.058 dengan asumsi variabel independen lainnya tetap.

3. Koefisien regresi leverage $\left(\mathrm{X}_{2}\right)$ sebesar -0.877 , artinya jika leverage mengalami peningkatan sebesar $1 \%$, maka akan diikuti penurunan konservatisme akuntansi $(\mathrm{Y})$ sebesar -0.877 dengan asumsi variabel independen lainnya tetap.

4. Koefisien regresi likuiditas $\left(\mathrm{X}_{3}\right)$ sebesar -0.13 , artinya jika likuiditas mengalami peningkatan sebesar $1 \%$, maka akan diikuti penurunan konservatisme akuntansi (Y) sebesar -0.13 dengan asumsi variabel independen lainnya tetap.

5. Koefisien regresi risiko litigasi $\left(\mathrm{X}_{4}\right)$ sebesar -0.023 , artinya jika risiko litigasi mengalami peningkatan sebesar $1 \%$, maka akan diikuti penurunan konservatisme akuntansi (Y) sebesar -0.023 dengan asumsi variabel independen lainnya tetap.

6. Koefisien regresi kepemilikan institusional $\left(X_{5}\right)$ sebesar 0.068 , artinya jika kepemilikan institusional mengalami peningkatan sebesar 1\%, maka akan diikuti peningkatan konservatisme akuntansi $(\mathrm{Y})$ sebesar 0.068 dengan asumsi variabel independen lainnya tetap.

7. Koefisien regresi kepemilikan asing $\left(\mathrm{X}_{6}\right)$ sebesar 0.699 , artinya jika kepemilikan asing mengalami peningkatan sebesar 1\%, maka akan diikuti peningkatan konservatisme akuntansi (Y) sebesar 0.699 dengan asumsi variabel independen lainnya tetap.

\subsection{Uji Hipotesis}

Uji $\mathrm{t}$ dilakukan untuk mengetahui pengaruh masing-masing variabel independen terhadap variabel dependen. Apabila hasil uji memiliki nilai signifikansi > 0.05 maka tidak terdapat pengaruh terhadap variabel dependen $(Y)$, sebaliknya jika hasil uji 


\section{Buana Akuntansi}

memiliki nilai signifikansi $<0.05$ maka terdapat pengaruh terhadap variabel dependen $(\mathrm{Y})$.

\begin{tabular}{|ll|r|r|}
\multicolumn{3}{c|}{$\begin{array}{c}\text { Tabel 6. Hasil Uji t } \\
\text { Coefficients }^{\mathbf{a}}\end{array}$} \\
\begin{tabular}{|ll|r|r|} 
Model & \multicolumn{1}{c|}{$\mathrm{t}$} & \multicolumn{1}{c|}{ Sig. } \\
\hline 1 & (Constant) & 3.667 & .001 \\
& FD & -2.405 & .021 \\
& LEV & -3.282 & .002 \\
& LIK & -.187 & .853 \\
& RL & -1.359 & .181 \\
& KI & .631 & .531 \\
& KA & 2.999 & .005 \\
\hline
\end{tabular}
\end{tabular}

Sumber: Output SPSS 26

1. Pengaruh Financial Distress terhadap Konservatisme Akuntansi

Nilai signifikansi financial distress sebesar $0.021<0.05$ sehingga financial distress berpengaruh terhadap konservatisme akuntansi. Dengan demikian maka hipotesis $\mathrm{H}_{1}$ yang menyatakan bahwa financial distress berpengaruh terhadap konservatisme akuntansi diterima.

2. Pengaruh Leverage terhadap Konservatisme Akuntansi

Nilai signifikansi yang ditunjukkan oleh variabel leverage sebesar $0.050 .002<0.05$ sehingga leverage berpengaruh terhadap konservatisme akuntansi. Dengan demikian maka hipotesis $\mathrm{H}_{2}$ yang menyatakan bahwa leverage berpengaruh terhadap konservatisme akuntansi diterima.

3. Pengaruh likuiditas terhadap Konservatisme Akuntansi

Nilai signifikansi yang ditunjukkan oleh variabel likuiditas sebesar $0.853>0.05$ sehingga likuiditas tidak berpengaruh terhadap konservatisme akuntansi. Dengan demikian maka hipotesis $\mathrm{H}_{3}$ yang menyatakan bahwa likuiditas berpengaruh terhadap konservatisme akuntansi ditolak.

4. Pengaruh risiko litigasi terhadap Konservatisme Akuntansi

Nilai signifikansi yang ditunjukkan oleh variabel risiko sebesar $0.181>0.05$ sehingga risiko litigasi tidak berpengaruh terhadap konservatisme akuntansi. Dengan demikian maka hipotesis $\mathrm{H}_{4}$ yang menyatakan bahwa risiko litigasi berpengaruh terhadap konservatisme akuntansi ditolak.

5. Pengaruh Kepemilikan Institusional terhadap Konservatisme Akuntansi

Nilai signifikansi yang ditunjukkan oleh variabel kepemilikan institusional sebesar $0.531>$ 0.05 sehingga kepemilikan institusional tidak berpengaruh terhadap konservatisme akuntansi. Dengan demikian maka hipotesis $\mathrm{H}_{5}$ yang menyatakan bahwa kepemilikan institusional berpengaruh terhadap konservatisme akuntansi ditolak.

6. Pengaruh Kepemilikan Asing terhadap Konservatisme Akuntansi

Nilai signifikansi yang ditunjukkan oleh variabel kepemilikan sebesar $0.005<0.05$ sehingga kepemilikan asing berpengaruh terhadap konservatisme akuntansi. Dengan demikian maka hipotesis $\mathrm{H}_{6}$ yang menyatakan bahwa kepemilikan asing berpengaruh terhadap konservatisme akuntansi diterima.

\section{$50 \mid J u r n a 1$ B u a a A untansi}




\section{Buana Akuntansi}

Tabel 7. Hasil Uji F

ANOVA

\begin{tabular}{|c|c|c|c|c|c|c|}
\hline & Model & $\begin{array}{l}\text { Sum of } \\
\text { Squares }\end{array}$ & Df & $\begin{array}{l}\text { Mean } \\
\text { Square }\end{array}$ & $\mathrm{F}$ & Sig. \\
\hline \multirow[t]{3}{*}{1} & Regression & .804 & 6 & .134 & 6.281 & $.000^{\mathrm{b}}$ \\
\hline & Residual & .875 & 41 & .021 & & \\
\hline & Total & 1.678 & 47 & & & \\
\hline
\end{tabular}

Sumber: Output SPSS 26

Dari tabel diatas, dapat disimpulkan bahwa nilai Signifikansi lebih kecil dari $0.05(0.00<$ 0.05) sehingga variabel financial distress, leverage, likuiditas, risiko litigasi, kepemilikan institusional dan kepemilikan asing secara bersama-sama berpengaruh simultan terhadap konservatisme akuntansi.

Tabel 8. Hasil Uji Koefisien Determinasi $\left(\mathbf{R}^{2}\right)$ Model Summary

\begin{tabular}{|l|r|r|}
\hline & \multicolumn{1}{c|}{$\begin{array}{c}\text { Adjusted R } \\
\text { Square }\end{array}$} & \multicolumn{1}{c|}{$\begin{array}{c}\text { Std. Error of } \\
\text { the Estimate }\end{array}$} \\
\hline 1 & .442 & .11165 \\
\hline
\end{tabular}

Sumber: Output SPSS 26

Dari tabel diatas dapat disimpulkan bahwa nilai Adjusted $R$ Square sebesar 0.442 atau 44.2\%. Hal ini berarti variabel financial distress, leverage, likuiditas, risiko litigasi, kepemilikan institusional dan kepemilikan asing dalam penelitian ini dapat menjelaskan $44.2 \%$ variabel konservatisme akuntansi, sedangkan 55.8\% dijelaskan oleh variabel lain yang tidak dimasukkan dalam penelitian ini.

\subsection{Pembahasan}

\subsubsection{Pengaruh Financial Distress terhadap Konservatisme Akuntansi}

Financial distress berpengaruh terhadap konservatisme akuntansi. Hal ini dapat dilihat dari nilai signifikansi sebesar 0.021 lebih kecil dari $0.05(0.021<0.05)$ dengan nilai $t_{\text {hitung sebesar - }}$ 2.405 dengan demikian maka hipotesis $\mathrm{H}_{1}$ diterima. Hasil penelitian ini didukung oleh penelitan sebelumnya oleh Budi Santoso (2018), Agung, Nurcholisa dan Nurhayati (2019), Putri (2018), dan Risdiyani (2015) yang menyatakan bahwa financial distress berpengaruh negatif signifikan terhadap konservatisme akuntansi.

\subsubsection{Pengaruh Leverage terhadap Konservatisme Akuntansi}

Variabel leverage berpengaruh terhadap konservatisme akuntansi. Hal ini dapat dilihat dari nilai signifikansi sebesar 0.002 lebih kecil dari $0.05(0.002<0.05)$ dengan nilai thitung sebesar 3.282 dengan demikian maka hipotesis $\mathrm{H}_{2}$ diterima. Pada penelitian yang dilakukan oleh Esa Anti Ursula dan Vidya Vitta Adhivinna (2018) menyatakan bahwa pada saat perusahaan memiliki tingkat leverage yang tinggi perusahaan akan menggunakan pilihan kebijakan akuntansi untuk memperbaiki rasio keuangan. Besanya rasio leverage yang dimiliki oleh

\section{J u rna 1 B u a a A kuntansi}


perusahaan menunjukkan bahwa kemampuan perusahaan dalam melunasi kewajiban jangka panjang rendah hal ini dapat menimbulkan kurangnya ketidak percayaan pemberi pinjaman maka dari itu perusahaan akan menyajikan laporan keuangan yang konservatif dengan cara menaikkan nilai aset dan pendapatan serta menurunkan nilai utang dan beban. Hasil ini sesuai dengan penelitian sebelumnya oleh Egi Putra Utama dan Dr. Farida Titik (2018) yang menunjukkan bahwa leverage berpengaruh signifikan dengan arah negatif terhadap konservatisme akuntansi.

4.5.3. Pengaruh Likuiditas terhadap Konservatisme Akuntansi

Variabel likuiditas tidak berpengaruh terhadap konservatisme akuntansi. Hal ini dapat dilihat dari nilai signifikansi sebesar 0.853 lebih besar dari $0.05(0.853>0.05)$ dengan nilai $t_{\text {hitung }}$ sebesar -0.187 dengan demikian maka hipotesis $\mathrm{H}_{3}$ ditolak. Karena pada dasarnya likuiditas berhubungan dengan kepercayaan kreditor kepada perusahaan, artinya semakin tinggi likuiditas maka semakin tinggi pula kepercayaan para kreditor terhadap perusahaan, maka perusahaan akan tetap berusaha menjaga kinerja perusahaannya agar tetap mendapat kepercayaan dari kreditor salah satu caranya adalah dengan menerapkan prinsip konservatisme yang optimis maupun pesimisme. Hasil ini sesuai dengan penelitian yang dilakukan oleh Radyasinta Surya Pratanda dan Kusmuriyanto (2014) yang menyatakan bahwa variabel likuiditas tidak berpengaruh terhadap konservatisme akuntansi.

\section{|4.5.4. Pengaruh Risiko Litigasi terhadap Konservatisme Akuntansi}

Variabel risiko litigasi tidak berpengaruh terhadap konservatisme akuntansi. Hal ini dapat dilihat dari nilai signifikansi sebesar 0.181 lebih besar dari $0.05(0.181>0.05)$ dengan nilai thitung sebesar -1.359 dengan demikian maka hipotesis $\mathrm{H}_{4}$ ditolak. Hasil penelitian ini sejalan dengan penelitian yang dilakukan oleh Agi Pratama, Dr. Norita dan Annisa Nurbaiti (2016) yang menyatakan bahwa risiko litigasi tidak berpengaruh signifikan dengan arah negatif terhadap konservatisme akuntansi.

\subsubsection{Pengaruh Kepemilikan Institusional terhadap Konservatisme Akuntansi}

Variabel kepemilikan institusional tidak berpengaruh terhadap konservatisme akuntansi. Hal ini dapat dilihat dari nilai signifikansi sebesar 0.531 lebih besar dari $0.05(0.531>0.05)$ dengan nilai $t_{\text {hitung }}$ sebesar 0.631 dengan demikian maka hipotesis $\mathrm{H}_{5}$ ditolak. Kepemilikan institusional yang besar mendorong perusahaan untuk menunjukkan kinerja yang lebih baik dengan ditandai laba yang meningkat sehingga para investor mendapatkan return dalam bentuk deviden maupun capital gain yang besar atas investasinya, sehingga ada kecenderungan perusahaan melakukan manajemen laba untuk melaporkan laba yang tinggi sehingga perusahaan cenderung tidak menyajikan laporan keuangan yang konservatif. . Hasil penelitian ini sejalan dengan penelitian yang dilakukan oleh Syifa, Kristanti dan Dillak (2017) yang menyatakan bahwa kepemilikan institusional tidak berpengaruh terhadap konservatisme akuntansi

\subsubsection{Pengaruh Kepemilikan Asing terhadap Konservatisme Akuntansi}

Berdasarkan pada tabel 24 diatas, dapat diketahui bahwa variabel kepemilikan asing berpengaruh terhadap konservatisme akuntansi. Hal ini dapat dilihat dari nilai signifikansi

\section{$52 \mid J u r n a 1$ B uana A kuntansi}


sebesar 0.005 lebih kecil dari $0.05(0.005>0.05)$ dengan nilai $t_{\text {hitung }}$ sebesar 2.999 dengan demikian maka hipotesis $\mathrm{H}_{6}$ diterima. Pada hasil penelitian yang dilakukan oleh Amneh Alkurdi (2017) menyatakan bahwa kepemilikan asing dapat meningkatkan penyajian laporan keuangan yang konservatif karna dapat mengurangi asimetri informasi dan menghindari pilihan oportunistik manajemen, sehingga kepemilikan asing lebih mampu mengendalikan kebijakan manajemen. Hal ini tentunya dapat meningkatkan transparansi dalam penyajian laporan keuangan.

Hasil ini sesuai dengan penelitian sebelumnya oleh Indhira Kuspratiwi dan Ari Kuncara Widagdo (2014) yang menyatakan bahwa kepemilikan saham asing berpengaruh signifikan terhadap konservatisme akuntansi.

\section{Kesimpulan dan Saran}

\subsection{Kesimpulan}

1. Variabel financial distress berpengaruh signifikan terhadap konservatisme akuntansi pada sektor BUMN yang terdaftar di Bursa Efek Indonesia periode 2014-2019.

2. Variabel leverage berpengaruh signifikan terhadap konservatisme akuntansi pada sektor BUMN yang terdaftar di Bursa Efek Indonesia periode 2014-2019 .

3. Variabel likuiditas berpengaruh signifikan terhadap konservatisme akuntansi pada sektor BUMN yang terdaftar di Bursa Efek Indonesia periode 2014-2019.

4. Variabel risiko litigasi berpengaruh signifikan terhadap konservatisme akuntansi pada sektor BUMN yang terdaftar di Bursa Efek Indonesia periode 2014-2019.

5. Variabel kepemilikan institusional tidak memiliki pengaruh signifikan terhadap konservatisme akuntansi pada sektor BUMN yang terdaftar di Bursa Efek Indonesia periode 2014-2019.

6. Variabel kepemilikan asing berpengaruh signifikan terhadap konservatisme akuntansi pada sektor BUMN yang terdaftar di Bursa Efek Indonesia periode 2014-2019.

7. Berdasarkan hasil pengujian secara simultan, diperoleh bahwa variabel financial distress, leverage, likuiditas, risiko litigasi, kepemilikan institusional dan kepemilikan asing secara bersama-sama berpengaruh terhadap konservatisme akuntansi

8. Hasil dari nilai koefisien determinasi $\left(\mathrm{R}^{2}\right)$ sebesar 0.442 , hal ini berarti bahwa variabel financial distress, leverage, likuiditas, risiko litigasi, kepemilikan institusional dan kepemilikan asing dalam penelitian ini hanya dapat menjelaskan $44.2 \%$ variabel konservatisme akuntansi, sedangkan sisanya dijelaskan oleh variabel lain yang tidak dimasukkan dalam penelitian ini.

\subsection{Saran-Saran}

Berdasarkan kesimpulan diatas, penulis mengemukakan beberapa saran-saran sebagai berikut:

1. Perusahaan disarankan untuk lebih berhati-hati dalam menyajikan laporan keuangan, karna banyak faktor-faktor tertentu yang dapat membahayakan kelangsungan hidup perusahaan apabila perusahaan tidak menerapkan prinsip kehati-hatian.

2. Bagi para investor disarankan lebih cerdas dan selektif dalam memilih perusahaan sebelum melakukan investasi. Sebaiknya, para investor memperhatikan tingkat financial distress, leverage, dan kepemilikan asing, karena hal tersebut berkaitan dengan penerapan

\section{3 | J u r n a 1 B a n a A k n t a n si}


konservatisme akuntansi sehingga para investor terhindar dari risiko tuntutan hukum yang dapat memberatkan.

3. Untuk penelitian selanjutnya disarankan untuk menambah sampel yang lebih banyak, variabel yang lebih luas lagi, dan memperpanjang rentang waktu penelitian sehingga dapat memperkuat kesimpulan dari hasil penelitian-penelitian yang terdahulu mengingat $55.8 \%$ variabel lain dapat menjelaskan konservatisme akuntansi.

\section{Daftar Pustaka}

Abdurrahman, Muhammad Affan., dan Ernawati, Wita Juwita (2018). Pengaruh Leverage, Financial Distress dan Profitabilitas terhadap Konservatisme Akuntansi. Jurnal Manajemen dan Organisasi (JMO), Vol. 9 No. 3. Bogor : Institut Pertanian Bogor.

Agung, J. R., Nurcholisa, K., \& Nurhayati, N. (2019). Pengaruh Financial Distress dan Kepemilikan Institusional terhadap Konservatisme Akuntansi (Studi Empiris Pada Perusahaan Sektor Pertambangan yang Terdaftar di Bursa Efek Indonesia periode tahun 2015-2017).

Agus Sartono. 2014. Manajemen Keuangan Teori dan Aplikasi. Edisi empat. Cetakan ke tujuh Yogyakarta:Penerbit BPFE

Alkordi, A., Al-Nimer, M., \& Dabaghia, M. (2017). Accounting conservatism and ownership structure effect: Evidence from industrial and financial Jordanian listed companies. International Journal of Economics and Financial Issues, 7(2), 608-619.

Aristiyani, D. G. U., \& Wirawati, I. G. P. (2013). Pengaruh Debt To Total Assets, Dividen Payout Ratio dan Ukuran Perusahaan pada Konservatisme Akuntansi Perusahaan Manufaktur di BEI. EJurnal Akuntansi Universitas Udayana, 3(3), 216-230.

Arsita, M. A., \& Kristanti, F. T. (2019). Pengaruh Leverage, Profitabilitas, Kepemilikan Manajerial, Intensitas Modal Dan Ukuran Perusahaan Terhadap Konservatisme Akuntansi (studi Empiris Pada Perusahaan Sub Sektor Food and Beverages Yang Terdaftar Di Bursa Efek Indonesia Periode 2014-2017). eProceedings of Management, 6(2).

Brigham, Eugine F., and Houston, Joel F. (2013). Dasar-Dasar Manajemen Keuangan (Edisi 11), Buku 2. Jakarta: Salemba Empat

Brilianti, D. P. (2013). Pengaruh kepemilikan manajerial, kepemilikan institusional, leverage dan komite audit terhadap konservatisme akuntansi (Doctoral dissertation, Universitas Negeri Semarang).

Dewi, Ni Kd S. L., Suryanawa, I Ketut (2014). Pengaruh Struktur Kepemilikan Manajerial, Leverage, dan Financial Distress Terhadap Konservatisme Akuntansi. E-Jurnal Akuntansi Universitas Udayana. Bali : Universitas Udayana.

El-Haq, Z. N. S., Zulpahmi, Z., \& Sumardi, S. (2019). Pengaruh Kepemilikan Manajerial, Kepemilikan Institusional, Growth Opportunities, dan Profitabilitas terhadap Konservatisme Akuntansi. Jurnal ASET (Akuntansi Riset), 11(2), 315-328

Fahmi, Irham. (2015). Analisis Laporan Keuangan, Cetakan Ke-5. Bandung: Alfabeta.

Fathurahmi, A., Sukarmanto, E., \& Fadilah, S. (2019). Pengaruh Growth Opportunities dan Financial Distress terhadap Conservatism Accounting pada Perusahaan Textile dan Garment Yang Terdaftar di Pt. Bursa Efek Indonesia Periode 2010-2014.

Geimechi, G., dan Khodabakhshi, N. (2015). Factors Affecting the Level of Accounting Conservatism In The Financial Statements of the Listed Companies In Tehran Stock Exchange. International Journal Of Accounting Research Vol.2, No.4.

Hery. (2016). Analisis Laporan Keuangan. Jakarta : PT Gramedia Widia Sarana Indonesia.

\section{4 | J u n a 1 B u a a A k ntansi}


Kao, H. S., \& Sie, P. J. (2016). Accounting Conservatism Trends and Financial Distress: Considering the Endogeneity of the C-Score. International Journal of Financial Research, 7(4), 149-167.

Mahariana, I. D. G. P., \& Ramantha, I. W. (2014). Pengaruh Kepemilikan Manajerial dan Kepemilikan Institusional terhadap Manajemen Laba Pada Perusahaan Manufaktur di BEI. E-Jurnal Akuntansi, 688-699.

Maux, J. L., \& Francoeur, C. (2013). Block Premia, Litigation Risk, and Shareholder Protection. European Financial Management, 20(4), 756-769.

Ningsih, E. (2013). Pengaruh Tingkat Kesulitan Keuangan Perusahaan Dan Risiko Litigasi Terhadap Konservatisme Akuntansi (Studi Empiris pada Perusahaan Manufaktur yang Terdaftar di $B E I)$. Jurnal Akuntansi, 1(1).

Noviantari, N. W., \& Ratnadi, N. M. D. (2015). Pengaruh Financial Distress, Ukuran Perusahaan, Dan Leverage Pada Konservatisme Akuntansi. E-Jurnal Akuntansi Universitas Udayana, 11(3), 646-660.

Nuraeni, C., \& Tama, A. I. (2019). Effect of Managerial Ownership, Debt Covenant, Political Cost And Growth Opportunities On Accounting Conservatism Levels. International Journal of Economics, Business and Accounting Research (IJEBAR), 3(03).

Pratama, A., Norita, N., \& Nurbaiti, A. (2016). Pengaruh Tingkat Kesulitan Keuangan, Risiko Litigasi, Dan Growth Opportunities Terhadap Konservatisme Akuntansi (studi Kasus Pada Perusahaan Sub Sektor Telekomunikasi Yang Terdaftar Di Bursa Efek Indonesia Tahun 20112015). eProceedings of Management, 3(3).

Pratanda, R. S., \& Kusmuriyanto, K. (2014). Pengaruh mekanisme good corporate governance, likuiditas, profitabilitas, dan leverage terhadap konservatisme akuntansi. Accounting Analysis Journal, 3(2).

Rahayu, S., \& Gunawan, D. I. (2018). Factors Influencing the Application of Accounting Conservatism in the Company. KnE Social Sciences, 180-197.

Rahayu, Sri., Kusmuriyanto., Kisanto., dan Gunawan, D. I (2018). Factors Influencing the Application of Accounting Conservatism in the Company. Internasional Conference on Economics, Business and Economic Education.

Risdiyani, F., \& Kusmuriyanto, K. (2015). Analisis Faktor-Faktor Yang Mempengaruhi Penerapan Konservatisme Akuntansi. Accounting Analysis Journal, 4(3).

Rizkyka, T., Nurhayati, N., \& Fadilah, S. (2019). Pengaruh Risiko Litigasi Dan Tingkat Kesulitan Keuangan Terhadap Konservatisme Akuntansi (Studi Empiris Pada Perusahaan Telekomunikasi Yang Terdaftar Di Bursa Efek Indonesia Periode 2010-2015). Prosiding Akuntansi, 3(2)

Savitri, Enni. (2016). Konservatisme Akuntansi. Yogyakarta : Pustaka Sahila.

Septianto, H. (2016). Pengaruh Debt Covenant, Financial Distress, Risiko Litigasi Dan Growth Opportunities Terhadap Konservatisme Akuntansi (Bachelor's thesis, Jakarta: Fakultas Ekonomi dan Bisnis UIN Syarif Hidayatullah Jakarta).

Sugiyono. (2016). Metode Penelitian Kuantitatif, Kualitatif, dan RED. Bandung: Alfabet.

Susanto, B., \& Ramadhani, T. (2016). Faktor-faktor yang memengaruhi konservatisme (studi pada perusahaan manufaktur yang terdaftar di BEI 2010-2014). Jurnal Bisnis Dan Ekonomi, 23(2).

Suwardjono. (2014). Teori Akuntansi Perekayasaan Laporan Kuangan (Edisi Ketiga). Yogyakarta: BPFE.

Syifa, H. M., Kristanti, F. T., \& Dillak, V. J. (2017). Financial Distress, Kepemilikan Institusional, Profitabilitas Terhadap Konservatisme Akuntansi. Jurnal Riset Akuntansi Kontemporer (JRAK), 9(1).

\section{5 | Jurnal Buana A kuntansi}




\section{Buana Akuntansi}

Utama, E. P., \& Titik, F. (2018). Pengaruh Leverage, Ukuran Perusahaan, Kepemilikan Manajerial Dan Profitabilitas Terhadap Konservatisme Akuntansi (Studi Pada Subsektor Telekomunikasi Yang Terdaftar Di Bursa Efek Indonesia Periode 2011-2016). eProceedings of Management, 5(1).

Wisuandari, N. K. P., dan Putra, I. N. W (2018). Pengaruh Tingkat Kesulitan Keuangan dan Konflik Kepentingan pada Konservatisme Akuntansi dengan Risiko Litigasi Sebagai Pemoderasi. E-Jurnal Akuntansi Universitas Udayana. Vol.23.2. Bali : Universitas Udayana. 